\title{
MENINGKATKAN KEMAMPUAN PENALARAN MATEMATIS MELALUI PEMBELAJARAN MODEL RECIPROCAL TEACHING
}

\author{
Muhsin \\ ( Dosen Pendidikan Matematika FKIP Universitas Jabal Ghafur Sigli)
}

\begin{abstract}
ABSTRAK
Abstrak: Kemampuan penalaran matematis siswa SMP masih rendah, hal ini merupakan salah satu masalah utama dalam pendidikan matematika. Oleh karena itu perlu adanya model pembelajaran yang dapat meningkatkan kemampuan penalaran matematis siswa, salah satu pembelajaran yang dapat meningkatkan kemampuan ini adalah pembelajaran model reciprocal teaching. Penelitian ini bertujuan untuk menelaah perbedaan peningkatan kemampuan penalaran matematis antara siswa yang memperoleh pembelajaran dengan model reciprocal teaching dan siswa yang memperoleh pembelajaran konvensional. Penelitian ini merupakan suatu kuasi eksperimen dengan desain penelitian pre-test post-test control group design. Populasi adalah seluruh siswa kelas VII MTsN Beureunuen dengan mengambil sampel dua kelas (kelas eksperimen memperoleh pembelajaran dengan model reciprocal teaching dan kelas kontrol memperoleh pembelajaran konvensional) melalui teknik purposive sampling dari lima kelas paralel yang tersedia. Pengumpulan data menggunakan instrumen berupa tes kemampuan penalaran matematis. Untuk melihat adanya perbedaan peningkatan kemampuan siswa antara kelompok eksperimen dengan kelompok kontrol digunakan uji-t dengan taraf signifikan 0,05 setelah prasyarat pengujian terpenuhi. Hasil penelitian menunjukkan bahwa peningkatan kemampuan penalaran matematis siswa yang memperoleh pembelajaran dengan model reciprocal teaching lebih baik daripada siswa yang memperoleh pembelajaran konvensional.
\end{abstract}

Kata kunci: Pembelajaran dengan model reciprocal teaching, kemampuan penalaran matematis

\section{PENDAHULUAN}

Pendidikan memegang peranan yang sangat penting dalam upaya meningkatkan kualitas sumber daya manusia dalam menghadapi era kompetisi yang mengacu pada penguasaan ilmu pengetahuan dan teknologi. Mengingat sangat pentingnya pendidikan dalam kehidupan manusia, maka penyelenggaraan pendidikan harus dilakukan secara optimal, sehingga memperoleh hasil sesuai dengan yang diharapkan.

Pemerintah terus berusaha meningkatkan mutu pendidikan melalui berbagai inovasi (pembaharuan), diantaranya inovasi di bidang sistem pendidikan, kurikulum, buku pelajaran, metode pengajaran dan peningkatan kualitas guru sebagai pengajar. Inovasi dalam pendidikan matematika berkaitan dengan inovasi dalam pembelajaran matematika di sekolah. Salah satu faktor yang mempengaruhi mutu hasil pendidikan adalah terjadinya pembelajaran atau proses belajar mengajar yang baik sesuai dengan tujuan pendidikan.

Tujuan umum pembelajaran matematika menurut National Council of Teachers of Matematics atau NCTM (2000) yaitu siswa harus mempelajari matematika melalui pemahaman dan aktif membangun pengetahuan baru dari pengalaman dan pengetahuan yang dimiliki sebelumnya. Untuk mewujudkan hal itu, dirumuskan lima standar pokok pembelajaran matematika, yaitu: pertama belajar untuk berkomunikasi (mathematical communication); kedua, belajar untuk bernalar (mathematical reasoning); ketiga, belajar untuk memecahkan masalah (mathematical problem solving); keempat, belajar untuk mengaitkan pengertian ide (mathematical connections); dan kelima, pembentukan sikap positif terhadap matematika (positive attitudes toward mathematics).

Salah satu tujuan pembelajaran matematika adalah siswa memiliki kemampuan penalaran dan berpikir kritis. Depdiknas (2006) mengungkapkan "Materi matematika dan penalaran matematika merupakan dua hal yang tak dapat dipisahkan, yaitu materi matematika dipahami melalui penalaran dan penalaran dipahami dan dilatihkan melalui belajar materi matematika". Disaat belajar matematika, para siswa akan selalu dihadapkan dengan proses penalaran. Sejalan dengan hal tersebut, Shadiq (2007) berpendapat bahwa seni bernalar sangat dibutuhkan disetiap segi dan sisi kehidupan ini 
agar setiap warga bangsa dapat menunjukan dan menganalisis setiap masalah yang muncul secara jernih, dapat memecahkan masalah dengan tepat, serta dapat mengemukakan pendapat maupun idenya secara runtut dan logis.

Berdasarkan tujuan pembelajaran bahwa kemampuan penalaran perlu dikembangkan melalui proses pembelajaran matematika yang memberi keleluasan berpikir kepada siswa. Pemebelajaran tersebut harus berpusat kepada siswa, sedangkan peran guru dalam pembelajaran tidak hanya sebagai penyampai informasi saja melainkan sebagai fasilitator, motivator dan pembimbing yang akan memberikan kesempatan siswa untuk belajar aktif.

Pembelajaran yang dapat meningkatkan kemampuan penalaran matematis adalah pembelajaran yang memberi kesempatan dan kebebsan kepada siswa untuk menggunakan semua kemampuan berpikirnya. Pembelajaran berbalik (reciprocal teaching) adalah salah satu strategi pembelajaran matematika yang dapat meningkatkan kemampuan penalaran matematis.Mulyati (2007) mengatakan reciprocal teaching adalah model pembelajaran yang dirancang untuk meningkatkan pemahaman, penalaran dan berpikir kritis siswa terhadap bahan ajar. Prosedur-prosedur ini dirancang oleh Anne Marie Palinscar dari Miching State University dan Anne Brown dari the Universityof Illionis pada tahun 1984, dengan karakteristik sebagai berikut: (1) terjadi dialog antara siswa dengan guru, yang saling mengambil alih dalam peran menjadi pemimpin dialog; (2) reciprocal terjadi interaksi satu orang berperan merespon yang lainnya; (3) dialog disusun menggunakan 4 strategi yaitu mengajukan pertanyaan, merangkum, menjelaskan dan meramalkan

Berdasarkan uraian di atas penulis melaksanakan penelitian dengan judul "Meningkatkan Kemampuan Penalaran Matematis melalui Pembelajaran Model Reciprocal Teaching"

\section{KAJIAN PUSTAKA}

Suherman dan winata (Alamsyah, 2002:9) menungkapkan bahwa penalaran adalah proses berpikir yang dilakukan dengan cara untuk menarik kesimpulan. Kesimpulan yang bersifat umum dapat ditarik dari kasuskasus yang bersifat individual atau khusus. Ada dua macam penalaran dalam matematika yaitu penalaran deduktif dan penalaran induktif. Penalaran induktif menurut Hurley (Dwirahayu, 2006: 59) merupakan proses penarikan kesimpulan yang berdasarkan pada beberapa kemungkinan yang dimunculkan dari premis-premisnya. Artinya kita dapat menyimpulkan hal yang umum dari hal-hal khusus atau fakta-fakta yang dimunculkan pada premis-premisnya. Sedangkan Copi (Sumarmo, 2006: 34) mengungkapkan bahwa penalaran induksi adalah proses penalaran yang kesimpulannya diturunkan dari premispremisnya dengan suatu probabilitas. Dapat disimpulkan penalaran induktif merupakan kegiatan atau aktivitas berpikir untuk menarik kesimpulan dari yang bersifat khusus menjadi umum.

NCTM (1989: 81) mengemukakan bahwa standar kurikulum matematika yang memuat penalaran matematis untuk siswa kelas 5 - 8 (SMP) adalah dapat (1) mengenal dan menerapkan penalaran deduktif dan penalaran induktif; (2) memahami dan menerapkan proses-proses penalaran, khusunya penalaran spasial dan penalaran melalui proposisiproposiss dan grafik-grafik; (3) menyusun dan mengevaluasi konjektur-konjektur dan argumen-argumen matematika; (4) memvalidasi pikiran-pikiran siswa sendiri; dan (5) memahami kegunaan dan kekuatan penalaran sebagai bagian dari matematika.

Beberapa indikator penalaran matematis menurut Sumarmo (2006: 4) dalam pembelajaran matematika meliputi: (1) menarik kesimpulan logis; (2) memberikan penjelasan dengan model, fakta, sifat-sifat dan hubungan; (3) memperkirakan jawaban dan proses solusi; (4) menggunakan pola dan hubungan untuk menganalisis situasi matematik; (5) menyusun dan menguji konjektur; (6) merumuskan lawan contoh (counter example); (7) mengikuti aturan inferensi; (8) memeriksa validasi argumen, menyusun argumen yang valid; (9) menyusun pembuktian langsung dan menggunakan induksi matematik.

Menurut Palincsar dan Brown seperti yang dikutip oleh Slavin (1995) bahwa strategi reciprocal teaching adalah pendekatan konstruktivis yang didasarkan pada prinsipprinsip membuat pertanyaan, mengajarkan keterampilan metakognitif melalui pengajaran, dan pemodelan oleh guru untuk meningkatkan keterampilan membaca pada siswa yang berkemampuan rendah. Reciprocal teaching adalah prosedur pengajaran atau pendekatan 
yang dirancang untuk mengajarkan kepada siswa tentang strategi-strategi kognitif serta untuk membantu siswa memahami bacaan dengan baik Dengan menggunakan pendekatan reciprocal teaching siswa diajarkan empat strategi pemahaman dan pengaturan diri spesifik, yaitu merangkum bacaan, mengajukan pertanyaan, memprediksi materi lanjutan, dan mengklarifikasi istilah-istilah yang sulit dipahami.

Langkah-langkah reciprocal teaching adalah sebagai berikut:

1) Tahap pertama

Guru mempersiapkan bahan ajar. Guru membagi siswa dalam kelompok- kelompok kecil heterogen yang terdiri dari 4-5 orang siswa.

2) Tahap kedua

a. Guru memberikan bahan ajar, kemudian siswa membaca bahan ajar yang telah diberikan. Kemudian siswa berhenti secara periodik untuk memeriksa pemahaman dengan cara saling menanyakan hal-hal yang belum dimengerti.

b. Setelah selesai membaca, siswa diberi tugas untuk merangkum hal-hal yang penting, menyusun pertanyaan, menjelaskan dan menyususn prediksi dari hasil bacaan bahan ajar dengan cara berdiskusi dalam kelompok.

c. Setelah proses diatas selesai, siswa diminta mengerjakan LKS, guru memberikan pengarahan dan bimbingan seperlunya dagi kelompok siswa yang mengalami kesulitan dalam menyelesaikan soal-soal LKS

d. Guru memperagakan peran sebagai pemimpin dialog dengan menjelaskan bahan ajar yang telah disimpulkan, menyampaikan pertanyaan-pertanyaan atau memberikan rangsangan kepada siswa untuk menyusun prediksi dari bahan ajar.

e. Guru menjelaskan bahwa pada pertemuan berikutnya akan dipilih seorang anggota kelompok secara acak yang berperan sebagai dialog.

f. Pada akhir pembelajaran, siswa yang termasuk kategori berkemampuan rendah diberikan tugas tambahan.

3) Tahap ketiga

Seperti pertemuan sebelumnya, guru membagikan bahan ajar dan siswa berdiskusi dalam kelompok dengan melakukan aktivitas reciprocal teaching. Kemudian dipilih seorang siswa untuk menjadi pemimpin dialog yang berperan aktif bersama teman-temannya membahas bahan ajar.

\section{METODE PENELITIAN}

Jenis penelitian yang digunakan adalah kuasi eksperimen dengan rancangan pretestposttest control group design yang menggunakan kelas eksperimen dan kelas kontrol. Kelas eksperimen adalah kelompok siswa yang diberi perlakuan pembelajaran model reciprocal teaching sedangkan kelas kontrol adalah kelompok siswa yang diberi pembelajaran konvensional. Populasi penelitian adalah siswa kelas VII MTsN Beureunuen yang terdiri dari lima kelas. Sampel penelitian adalah siswa kelas VII-1 dan VII-2, teknik pengambilan sampel pada penelitian ini dilakukan secara purposive sampling. Kelas VII-1 merupakan kelas eksperimen dan kelas VII-2 merupakan kelas kontrol.

Data hasil tes kemampuan penalaran matematis siswa sebelum dan sesudah pembelajaran dengan pembelajaran model reciprocal teaching, dianalisa dengan cara membandingkan skor pretes dan posttes. Pengujian ini dilakukan untuk data skor gain ternormalisasi kemampuan penalaran matematis. Uji statistik menggunakan Uji Levene dengan kriteria pengujian adalah terima Ho apabila Sig. Based on Mean > taraf signifikansi $(=0,05)$. Uji perbedaan dua rata rata untuk data skor gain ternormalisasi pada kedua kelompok tersebut adalah jika rata-rata skor gain berdistribusi normal dan homogen maka uji statistik yang digunakan adalah Uji-t.

Pengembangan instrumen yang akan digunakan untuk mengukur kemampuan penalaran matematis dilakukan dengan melakukan uji coba di sekolah. Uji coba yang dilakukan bertujuan untuk mengukur kecukupan waktu serta keterbacaan soal. Soal tes yang baik harus melalui beberapa tahap penilaian diantaranya, analisis validitas, reliabilitas, daya pembeda dan tingkat kesukaran.

\section{HASIL DAN PEMBAHASAN}

Peningkatan kemampuan penalaran matematis siswa dapat dilihat pada rangkuman hasil perhitungan uji perbedaan rata-rata kemampuan penalaran matematis yang ditunjukkan pada tabel di bawah ini. 
Tabel 1: Uji Perbedaan Rata-rata GainTernormalisasi Kemampuan Penalaran Matematis

\begin{tabular}{|c|c|c|c|c|c|c|}
\hline $\begin{array}{c}\text { ssptí } \\
\text { ExLimquan }\end{array}$ & $\mathrm{K}: \mathrm{s}$ & $t$ & it & 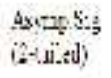 & 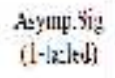 & Kesming in \\
\hline $\begin{array}{l}\text { Fresulera } \\
\text { Rivenetis }\end{array}$ & Fospution & $521 \mathrm{n}$ & 56 & $x_{1}$ & $50 \mathrm{~m}$ & $\begin{array}{l}\text { II livisk } \\
\text { Ileinh baiki }\end{array}$ \\
\hline
\end{tabular}

Berdasarkan tabel di atas dapat disimpulkan bahwa peningkatan kemampuan penalaran matematis siswa dengan pembelajaran model reciprocal teaching lebih baik daripada siswa dengan pembelajaran konvensional.

Setelah dilakukan pembelajaran model reciprocal teaching pada siswa kelompok eksperimen dan pembelajaran konvensional pada siswa kelompok kontrol, terdapat peningkatan kemampuan penalaran matematis siswa yang signifikan pada kelompok eksperimen. Namun, peningkatan kemampuan penalaran matematis siswa ini belum optimal, karena rerata peningkatan masih pada tingkat sedang. Peningkatan kemampuan penalaran matematis kelompok eksperimen sebesar 0,56 (kualifikasi n-gain tingkat sedang). Perbedaaan rerata n-gain kemampuan penalaran matematis antara siswa yang memperoleh pembelajaran model reciprocal teaching dengan siswa yang memperoleh pembelajaran konvensional 0,20. Peningkatan kemampuan penalaran matematis siswa yang mendapat pembelajaran model reciprocal teaching lebih baik dari pada siswa yang mendapat pembelajaran konvensional

Dengan demikian dapat disimpulkan bahwa, peningkatan kemampuan penalaran matematis siswa yang mendapat pembelajaran dengan pembelajaran model reciprocal teaching lebih baik daripada siswa yang mendapat pembelajaran konvensional, hal ini sesuai dengan penelitian yang dilakukan oleh Mulyati (2007) menyatakan bahwa peningkatan kemampuan berpikir kritis matematis antara siswa SMK yang memperoleh pembelajaran model reciprocal teaching lebih baik daripada siswa yang memperoleh pembelajaran konvensional. Begitu juga dengan penelitian. Juariah (2008) menunjukkan bahwa peningkatan kemampuan penalaran dan komunikasi matematis antara siswa yang memperoleh pembelajaran pendekatan keterampilan proses lebih baik daripada siswa yang memperoleh pembelajaran konvensional secara signifikan.

\section{KESIMPULAN DAN SARAN}

Kesimpulan

Adapun kesimpulan dari hasil penelitian adalah peningkatan kemampuan penalaran matematis siswa yang mendapat pembelajaran model reciprocal teaching lebih baik dibandingkan siswa yang mendapat pembelajaran konvensional. Dengan demikian pembelajaran matematika model reciprocal teaching dapat meningkatkan kemampuan penalaran matematis siswa.

Saran

Adapun saran-saran yang dapat penulis kemukakan adalah sebagai berikut:

1. Bagi para guru matematika, pembelajaran dengan model reciprocal teaching dapat dijadikan sebagai salah satu alternatif metode pembelajaran untuk diimplementasikan dalam pengembangan pembelajaran matematika di kelas.

2. Bagi peneliti berikutnya agar menelaah kelemahan pembelajaran ini dan juga agar menelaah pembelajaran ini untuk dilihat pengaruhnya pada kemampuan matematis lainnya seperti kemampuan koneksi, kemampuan pemecahan masalah, serta kemampuan berpikir kreatif dan lain sebagainya.

\section{DAFTAR PUSTAKA}

Alamsyah. (2002). Suatu Pembelajaran untuk Meningkatkan Kemampuan Penalaran Analogi Matematika.Bandung:Tesis Program Pascasarjana UPI. Tidak diterbitkan

Departemen Pendididikan Nasional. (2006). Kurikulum Tingkat Satuan Pendidikan (KTSP). Jakarta: Depdiknas.

Juariah. (2008). Upaya Meningkatkan Penalaran dan Komunikasi Matematis Siswa Melalui Pendekatan Proses. Tesis pada PPS Universitas Pendidikan Indonesia Bandung: Tidak dipublikasikan

Mulyati, T. (2007). Meningkatkan Kemampuan Berpikir Kritis Siswa dalam Matematika Melalui Reciprocal Teaching. Tesis pada PPS Universitas 
Pendidikan Indonesia Bandung: Tidak dipublikasikan

NCTM. (1989). Curiculum and Evaluation Standards for School Mathematics. Reston.VA:NCTM

NCTM.(2000). Principles and Standards for School Mathematics. Reston. VA: NCTM

Shadiq, F. (2007). Penalaran atau Reasoning Mengapa Perlu Dipelajari Para Siswa di
Sekolah?[Online].Tersedia:http://fadjar p3g.files.wordpress.com/2007/09/okpe nalarangerbang.pdf. [14 januari 2017]

Slavin, R.E. (1995). Cooperative Learning : Theory, Research, and Practice (second ed.) . Boston: Allyn and Bacon.

Sumarmo, U. (2006). Pembelajaran Keterampilan Membaca Matematika pada Siswa Sekolah Menengah. FPMIPA UPI: Tidak diterbitkan 